\title{
The Identification of the Existence of Dispersive Soil on the Soft Soil for Dam Filling Material
}

\author{
Lusmeilia Afriani ${ }^{1, *}$, Ryzal Perdana ${ }^{2}$ \\ ${ }^{1}$ Faculty of Engineering, Universitas Lampung, Indonesia \\ ${ }^{2}$ Department of Educational Science, Universitas Lampung, Indonesia
}

Received September 12, 2021; Revised November 29, 2021; Accepted January 16, 2022

\section{Cite This Paper in the following Citation Styles}

(a): [1] Lusmeilia Afriani, Ryzal Perdana, "The Identification of the Existence of Dispersive Soil on the Soft Soil for Dam Filling Material," Civil Engineering and Architecture, Vol. 10, No. 1, pp. 388-394, 2022. DOI: 10.13189/cea.2022.100133.

(b): Lusmeilia Afriani, Ryzal Perdana (2022). The Identification of the Existence of Dispersive Soil on the Soft Soil for Dam Filling Material. Civil Engineering and Architecture, 10(1), 388-394. DOI: 10.13189/cea.2022.100133.

Copyright $(2022$ by authors, all rights reserved. Authors agree that this article remains permanently open access under the terms of the Creative Commons Attribution License 4.0 International License

\begin{abstract}
Dispersive clay soils are highly erodible, even under standing water conditions. Dispersive clay soils are easily eroded both on the surface and in landfills, despite their high plasticity index and ability to be passed by water flows at low velocities. Dispersive soil will cause a variety of problems in dams and water structures, including the potential for seepage patterns in the embankment material, which can trigger piping, compromising the stability of the water structure. Dispersive soils occurring in many parts of the world are easily erodible and deflocculated in water, posing serious problems for stability of the earth and earth-retaining structures. Earth dams constructed on dispersive soils have sustained internal and external soft soil damage. The purpose of the current study was to identify the predetermine of dispersive clay soil as a filling material for the Way Sekampung Dam in Indonesia. Pinhole and Crumb tests were carried out to determine the dispersity of the original soil. This study analysed 17 undisturbed soil samples collected from 17 different locations throughout the study area. The research findings indicate that there is no evidence of dispersive soil distribution in the samples studied. According to the Pinhole and Crumb tests, all soil samples have ND-1 and 1 status, respectively. These findings are supported by laboratory test results which indicate that the soil content with a diameter greater than $0.005 \mathrm{~mm}$ is always less than $12 \%$ for each sample. In addition, another test revealed that the permeability value of all tested clay samples was not too low (around $10^{-2}$ to $10^{-4}$ ), indicating that they did not possess the properties of dispersive clay, which had a very low permeability value
\end{abstract}

(around $10^{-6}$ to $10^{-7}$ ). In general, the clay surrounding the dam site is free from dispersive properties and is therefore safe and suitable for use as a dam filling material. Finally, these findings will be beneficial for dam constructions to understand the possibility of dispersive soil causing significant issues that require attention in geotechnical engineering.

Keywords Identification, Existence, Dispersive, Soil, Dam Filling

\section{Introduction}

Every type of structure, including buildings, embankments, and dams, is generally constructed using the same procedures [1], [2]. For instance, any structure must be built on soil that is capable of bearing the loads above it. If the ground cannot withstand the vertical and horizontal forces generated by the loads above it, the building's construction will fail [3]. To avert this failure, either the structure must be relocated or the soil stabilised [4]. On the basis of these facts, it can be stated that soil is a critical component of any construction project. The soil ground is the area on which a building is constructed while also supporting the construction load [5].

When constructing a structure, we always strive to obtain suitable soil for the building's foundation. However, not all soils live up to our expectations. Certain areas deposit softer soils, such as clay. Clay is composed of 
mineral particles that range in size from less than $4 \mathrm{~mm}$ to inches. Clay is composed of silica and fine aluminium and is formed when silica rocks are weathered by carbonic acid [6], [7]. Some clay is formed as a result of geothermal activity. When dry, clay forms hard lumps; when wet, it becomes sticky [8]. Clay in construction frequently causes problems due to the soil's low bearing capacity. Clay is also well-known for its characteristics as a difficult-to-handle type of soil. Three characteristics of soft clays are their lack of bearing capacity, high compressibility, and extremely long consolidation time [9]. Clay's weaknesses can result in a variety of losses, including a threat to construction safety due to structural instability.

While clay is not ideal for use as a building foundation or road embankment material, this does not negate the importance of clay as a building material. Clay has been used as a construction material throughout history; for example, it is processed and formed into bricks or tiles. Clay is relatively simple to extract by adding water and converting it into a variety of different types of construction materials [10]. In Indonesia, clay is frequently used to construct earth fill dams. Due to its low permeability, clay is frequently used as a filter layer in this construction[11]. Clay can also be used to fill dams, particularly in areas with abundant clay deposits. However, dispersive soil content or soil that is easily eroded when mixed with water is frequently found in the clay used for dam filling material. This is because of the high sodium content, which increases the amount of water in the clay soil and weakens the bonds between the clay particles. As a result, when exposed to water, the clay particles easily disintegrate [12], [13]. According to the sieve analysis, dispersive soil contains more than $12 \%$ soil particles with a diameter $>0.0005[14]$ and a plasticity index $>4$ [15].

The Way Sekampung Dam, located in Sukoharjo District, Pringsewu Regency, Lampung Province, is one of the dams being built by the Indonesian government. The dam was built in 2016 and is expected to be finished in 2020. The dam construction project has progressed $53.4 \%$ so far. This dam is a core fill type dam with a height of 30 meters above the riverbed. Figure 1 depicts the dam filling project framework.

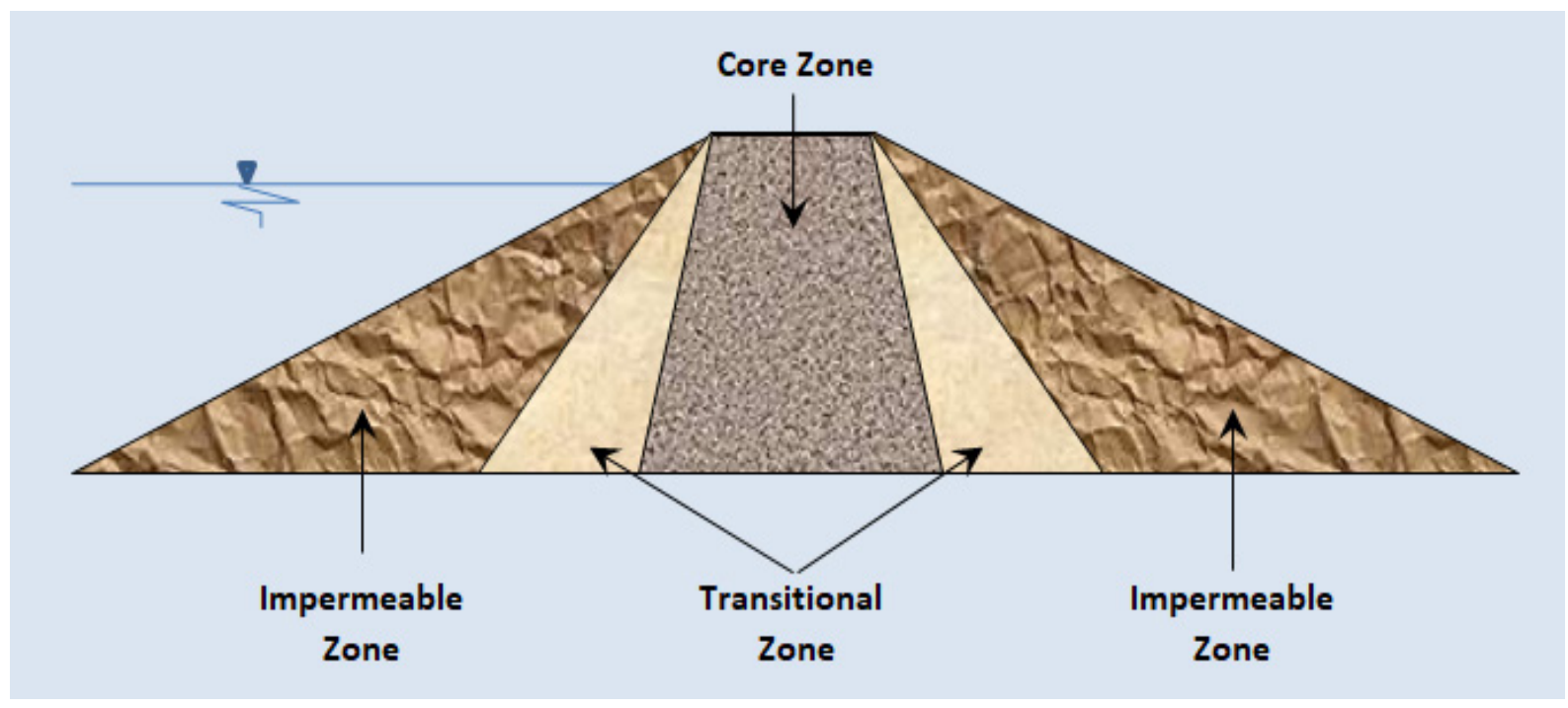

Figure 1. General scheme of central core fill type dam [16] 


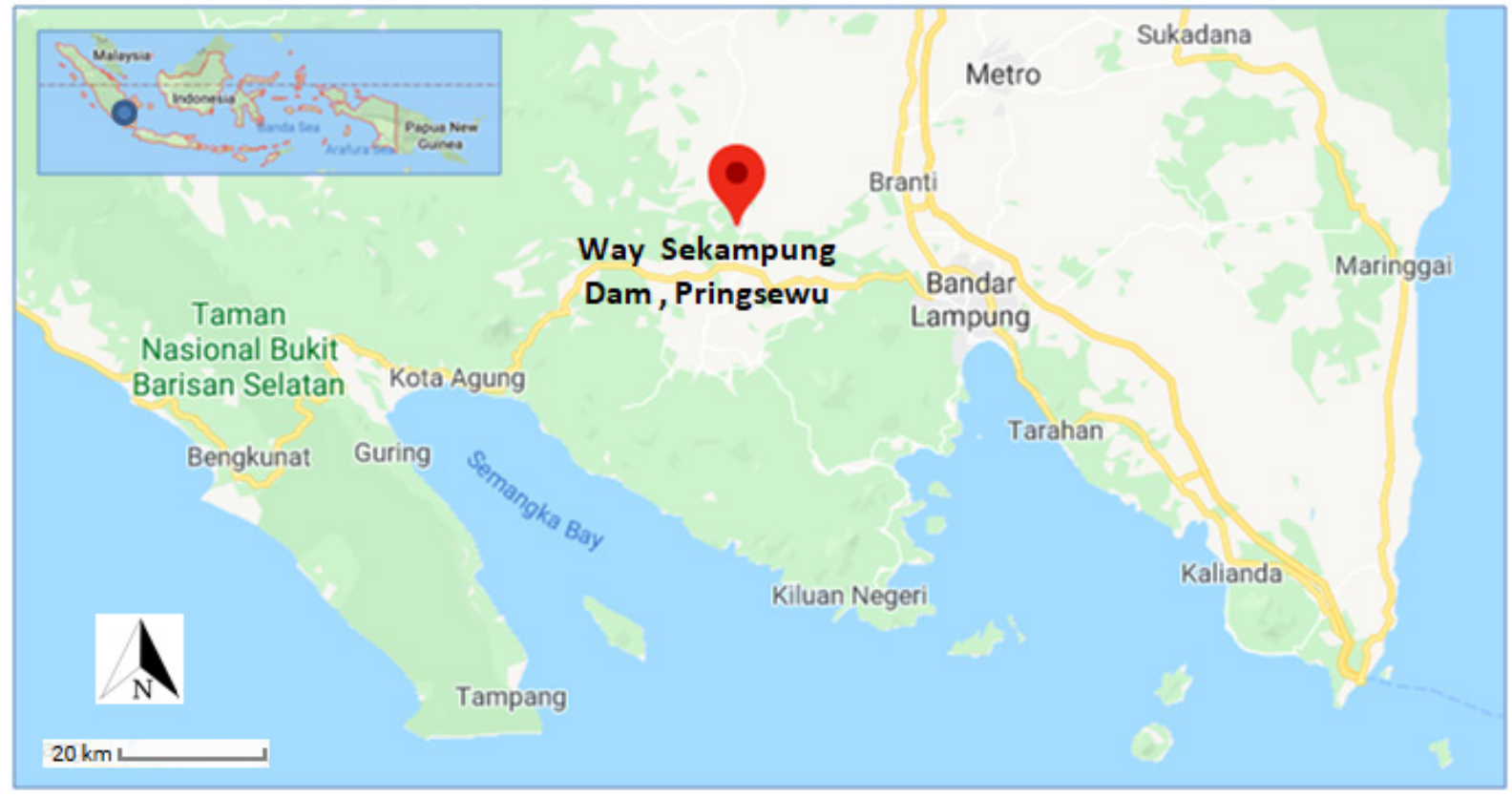

Figure 2. Location of Way Sekampung Dam

The impermeable zone is primarily made up of boulder rock, while the transitional and core zones are partly made up of clay. The presence of excess dispersive soil in the clay must be considered in a clay embankment plan to ensure the dam body's strength. Therefore, the goal of this study was to find out if there was dispersive soil in the clay that made up the Way Sekampung Dam's body and to make technical recommendations for improving the soil using a combination of other materials that reduce the amount of fine clay in the soil. As a first step in the research, a dispersity test on the original soil was conducted, followed by a similar test on a sample in the laboratory. The clay soil dispersity test could be done in a number of ways: Exchangeable Sodium Percentage (ESP) test, pinhole test, crumb test, double hydrometer test, chemical test [13], [17]. However, only the Pinhole and Crumb tests were performed in this study.

\section{Research Methodology}

\subsection{Location of the Study}

The Way Sekampung Dam is located approximately 46 kilometres from Bandar Lampung, the capital of Lampung Province, Indonesia. The Way Sekampung Dam is fed by the Way Sekampung River and is part of the dam cascade in the Way Sekampung River Basin. The Batutegi Dam, Lampung Province's largest dam, is located upstream. Downstream is the Argoguruh Dam, which serves the approximately 65,000-hectare Sekampung irrigation area. The location of the research is depicted on the map (see Figure 2).
The Way Sekampung Dam's primary function is to regulate the discharge that originates upstream of the dam and flows into the Argoguruh Dam. This dam was previously known as the Regulating Dam. The Way Sekampung dam's normal inundation area is 124 ha to $\mathrm{ft} 2$, with a normal storage volume of 68 million $\mathrm{m}^{3}$. Soil samples were collected from several locations around the dam for this study, and the samples were analysed at the University of Lampung's soil mechanics laboratory in Bandar Lampung City.

\subsection{Pinhole Test}

Pinhole testing is a technique for determining the distribution characteristics of dispersive clay soil that will be or has been used in soil construction. The pinhole test, which was performed in the laboratory, is a quick test that provides immediate results. When field performance was compared to the Pinhole test results, a strong correlation was typically observed. The pinhole test was conducted in accordance with ASTM D4647/D4647M-13 [18]. The Pinhole test compresses soil samples at their natural moisture content into a plastic cylinder. By inserting a needle through the specimen's center, a hole is created. After that, distilled water of a specified height is pumped through the specimen's hole. Turbidity is closely monitored in the water. Water discharge and flow velocity are closely monitored to determine whether or not the holes in the sample are enlarging as a result of erosion. When water flows through a hole $1 \mathrm{~mm}$ to 1 inch in diameter under pressure at low water elevations, dispersive clay rapidly erodes. The hole's rapid expansion is evident in the increased flow rate and turbidity of the collected water. The following is the interpretation of the test results. 
- Soils classified as D-1 or D-2 are dispersive in a moderately dispersed state. This indicates that the soil is in need of additional treatment.

- Soil ND-1 demonstrates that the soil is not spreading, indicating that it does not require special treatment.

- Soil ND-2, ND-3, or ND-4 indicates that the soil has a slight to moderate spread, necessitating only minor treatment.

\subsection{Crumb Test}

The crumb test is the most straightforward method for detecting dispersive clays. Crumbs are frequently used as a supplement to other laboratory analyses during investigations. The crumb test was done by slowly placing a lump of soil ranging in size from $1 / 4$ to $3 / 8$ inch into a transparent plastic cup filled with distilled water weighing approximately 90 ounces of liquid. Unless the soil was extremely wet, the soil lump should be at its natural moisture content. The lumps were placed on the edge of the glass base and left there for at least 1 hour, undisturbed. The clot and water were observed after 1 hour, and the presence of colloid clouds in the water was assessed. After leaving the lump in the glass overnight, a second observation was suggested. Some soil types did not react after an hour, but they could cause significant reactions if left unattended for longer periods of time. The following is the interpretation of the test results:

- Soil grade 1: no colloid clouds were found, indicating that the soil was non-dispersive.

- Soil grade 2: colloid clouds were found only around the soil debris, indicating that the soil was non-dispersive.

- Soil grade 3: colloid clouds were quite far from the soil chunks, but they did not cover the bottom of the glass, and some of the bottom of the glass was still visible, indicating that the soil was dispersive.

- Soil grade 4: the clouds may not completely cover the bottom of the glass, but they did completely cover the circumference or the entire bottom of the glass was covered by colloid clouds, indicating that the soil was dispersive.
Although the crumb test could quickly detect dispersive soils, it is usually used in conjunction with the Pinhole test and the double hydrometer test. This is due to the Crumb test's inability to pinpoint the dispersed soil distribution in great detail. The Crumb test was carried out in accordance with D6572-20 standard [19].

\section{Results and Discussion}

This research used 17 undisturbed soil samples collected from 17 different locations throughout the study area. The soil samples were coded as: A.3, AL.6, AL.7a, AL.7b, AL.8a, AL.8b, AL.9a, AL.9b, TP.1, TP.1-1, TP.2-1, TP.4, TP.4-2, TP.8, TP.9, TP.11, TP.11-1. Table 1 shows the results of pinhole and crumb tests.

Table 1 shows that none of the samples examined had dispersive soil distribution. This demonstrates that the concern about dispersion in the dam filling material's clay soils was unfounded. This also demonstrates that the clay surrounding the dam site was of good quality and sufficient to fill the dam embankment. Several analyses comparing the results of the dispersity test with the results of the soil mechanics tests in the laboratory were carried out to strengthen the interpretation of the dispersity test results.

As explained by [14], dispersive soils usually have particles with a grain diameter greater than $0.005 \mathrm{~mm}$, accounting for more than $12 \%$ of the total. A regression equation was developed in this study to predict the percentage of soil particles with grain diameter greater than $0.005 \mathrm{~mm}$, which is the sieve based on the percentage of soil particles that passed the 200 sieves. The regression equation was as follows:

$$
\mathrm{Y}=100-(-0.005 \mathrm{X}+0.520)
$$

where:

$X$ : percentage of soil particles that pass through sieve \# $200(\%)$

$Y$ : particles with a grain diameter greater than $0.005 \mathrm{~mm}$ that pass through the sieve (\%)

Table 1. The results of Pinhole tests and Crumb Tests of the sample

\begin{tabular}{|c|c|c|c|c|c|c|c|}
\hline No. & Sample & Pinhole test & Crumb test & No. & Sample & Pinhole test & Crumb test \\
\hline 1 & A. 3 & ND-1 & 1 & 10 & TP.1-1 & ND-1 & 1 \\
\hline 2 & AL.6 & ND-1 & 1 & 11 & TP.2-1 & ND-1 & 1 \\
\hline 3 & AL.7a & ND-1 & 1 & 12 & TP.4 & ND-1 & 1 \\
\hline 4 & AL.7b & ND-1 & 1 & 13 & TP.4-2 & ND-1 & 1 \\
\hline 5 & AL.8a & ND-1 & 1 & 14 & TP.8 & ND-1 & 1 \\
\hline 6 & AL.8b & ND-1 & 1 & 15 & TP.9 & ND-1 & 1 \\
\hline 7 & AL.9a & ND-1 & 1 & 16 & TP.11 & ND-1 & 1 \\
\hline 8 & AL.9b & ND-1 & 1 & 17 & TP.11-1 & ND-1 & 1 \\
\hline 9 & TP.1 & ND-1 & 1 & & & & \\
\hline
\end{tabular}


Table 2. The estimation of particles with a grain diameter $>0.005 \mathrm{~mm}$ which escapes from the sieve (\%) which is based on percentage of soil particles that pass-through sieve \# 200 (\%)

\begin{tabular}{|c|c|c|c|}
\hline No. & Sample & $\begin{array}{l}\text { Percentage of soil particles that } \\
\text { pass through sieve \# 200 (\%) }\end{array}$ & $\begin{array}{l}\text { Percentage of soil particles with a grain diameter }>\mathbf{0 . 0 0 5} \text { mm which } \\
\text { escapes from the sieve (\%) }\end{array}$ \\
\hline 1 & A.3 & 76,34 & 99,87 \\
\hline 2 & AL.6 & 93,75 & 99,96 \\
\hline 3 & AL.7a & 80,29 & 99,89 \\
\hline 4 & AL.7b & 88,44 & 99,93 \\
\hline 5 & AL. $8 \mathrm{a}$ & 90,63 & 99,94 \\
\hline 6 & AL.8b & 72,73 & 99,85 \\
\hline 7 & AL.9a & 80,30 & 99,89 \\
\hline 8 & AL.9b & 64,75 & 99,80 \\
\hline 9 & TP. 1 & 62,95 & 99,79 \\
\hline 10 & TP.1-1 & 56,45 & 99,76 \\
\hline 11 & TP. $2-1$ & 51,95 & 99,74 \\
\hline 12 & TP. 4 & 44,56 & 99,70 \\
\hline 13 & TP.4-2 & 58,31 & 99,77 \\
\hline 14 & TP. 8 & 71,36 & 99,84 \\
\hline 15 & TP.9 & 64,64 & 99,80 \\
\hline 16 & TP.11 & 73,49 & 99,85 \\
\hline 17 & TP.11-1 & 64,91 & 99,80 \\
\hline & & & \\
\hline
\end{tabular}

Table 3. The permeability of soil sampled tested in the laboratory

\begin{tabular}{|c|c|c|c|c|c|}
\hline No. & Sample & Permeability & No. & Sample & Permeability \\
\hline 1 & A.3 & $2,80 \mathrm{E}-02$ & 10 & TP.1-1 & $1,88 \mathrm{E}-03$ \\
\hline 2 & AL.6 & $8,13 \mathrm{E}-03$ & 11 & TP.2-1 & $4,26 \mathrm{E}-03$ \\
\hline 3 & AL.7a & $3,11 \mathrm{E}-04$ & 12 & TP.4 & $2,14 \mathrm{E}-03$ \\
\hline 4 & AL.7b & $1,98 \mathrm{E}-02$ & 13 & TP.4-2 & $1,49 \mathrm{E}-03$ \\
\hline 5 & AL.8a & $1,46 \mathrm{E}-02$ & 14 & TP. 8 & $2,84 \mathrm{E}-03$ \\
\hline 6 & AL.8b & $9,37 \mathrm{E}-04$ & 15 & TP.9 & $8,89 \mathrm{E}-03$ \\
\hline 7 & AL.9a & $1,11 \mathrm{E}-03$ & 16 & TP. 11 & $9,51 \mathrm{E}-03$ \\
\hline 8 & AL.9b & $1,40 \mathrm{E}-03$ & 17 & TP.11-1 & $2,46 \mathrm{E}-03$ \\
\hline 9 & TP. 1 & $3,29 \mathrm{E}-03$ & & & \\
\hline
\end{tabular}

Table 2 shows that, in all samples, the percentage of particles with grain diameter greater than $0.005 \mathrm{~mm}$ that escaped the filter never exceeded $12 \%$. This means that the presence of dispersive soil in the clay that forms the body of the Way Sekampung Dam is not cause for concern. In addition, these results indicate that the modelling results are consistent with the results of the Pinhole and Crumb tests, which indicate that there is no dispersive clay distribution on the clay soil under study. Another test revealed that the permeability value of all tested clay samples was not excessively low (around $10^{-2}$ to $10^{-4}$ ), indicating that they did not possess the properties of dispersive clay, which had a very small permeability value (around $10^{-6}$ to $10^{-7}$ ). The permeability value for each soil sample can be seen in Table 3 .

A dispersive soil is structurally unstable [20]-[22]. In dispersive soils, the soil aggregates - small clods - collapse when the soil gets wet, because the individual clay particles disperse into solution. This structural collapse results in the soil to collapsing, losing porosity and becoming denser, thus restricting root growth of annual crops and pastures. Soils frequently disperse when they are sodic, which means they contain enough sodium to interfere with the structural stability of the soil. Clay particles have a negative charge on their surface [23], [24]; this charge is balanced by positively charged cations, such as $\mathrm{Ca}^{2+}, \mathrm{Mg}^{2+}, \mathrm{K}^{+}$and $\mathrm{Na}^{+}$, distributed around the surface of the clay. Cation exchange capacity (CEC) is a measure of the total number of exchange sites in a given mass of a soil. When the ratio of sodium to other ions at these exchange sites is high, clay particles are less tightly bound to one another, and the soil aggregates easily disperse when the soil becomes wet. When a dispersive soil wets, its structure collapses. Under the impact of rain, the soil slumps, soil pores collapse or are 
filled with dispersed clay particles. This results in a decrease in the amount of soil pore space. The effect of this varies according to the topsoil, subsoil or both is sodic. Sodic top soils are prone to surface sealing and hardening (surface crusting) when they dry. This results in ponding and decreased soil oxygen levels, leading to poor crop emergence and root growth. If water ponds for an extended period of time, it can result in root death. When wet, these soils become swampy and are prone to water erosion and compaction. As a result of this behavior, highly dispersive soils can rapidly transition from being too hard when dry to being too wet for seeding after rainfall. Dispersive subsoils, like the top soils, have low porosity with dense (massive) structure and high soil strength when dry [25], [26]. The movement of air into these subsoils is poor resulting in a deficiency of oxygen. Water infiltration is slow resulting in waterlogging or perched water tables. They are typically moderately to strongly alkaline in nature and frequently contain toxic levels of boron and salt, which inhibit root growth.

\section{Conclusions}

The identification of the existence of dispersive soil on the soft soil for the dam filling material in Way Sekampung Dam Indonesia has been discussed. The research has shown the comparison between soil dispersity testing in the field and soil mechanics testing in the laboratory. The results of the field tests, Pinhole and Crumb tests, indicated the absence of dispersive soil distribution on the dam filling material. The laboratory test results, which include the results of sieve analysis and permeability testing, support the results of the field test. The sieve analysis indicates that the soil content with a gradation diameter of $<0.005 \mathrm{~mm}$ does not exceed $12 \%$ of all soil samples. Meanwhile, the permeability test shows that all soil samples have the permeability values ranging from $10^{-2}$ to $10^{-4}$ which indicates that all soil samples have permeability properties that differ from dispersive soils. Some dispersive soils, such as cracking clays, are self-mulching. As the soil dries and shrinks, cracks form, introducing some structure and porosity into the soil; however, when the soil is rewetted, the soil disperses and much of this structure is lost. Structural instability as a result of high sodium is only a problem in loam or clay soils with more than $10 \%$ of clay [27]. Alkaline fine textured soils with $\mathrm{pHCa}(\mathrm{pH}$ measured in calcium chloride) of 7.5-8.5 or more are invariably sodic or strongly sodic when the $\mathrm{pHw}$ is greater than 8.5. However, not all sodic soils are alkaline. Finally, in general it can be concluded that the clay surrounding the dam site is free of dispersive properties and is therefore safe and suitable for use as a dam filling material. The findings of this research are critical for future research on the topic of dispersive soil as a dam filling material. Therefore, it is recommended for future researchers to focus more on dispersion soils, which are extremely prone to erosion due to their high reactivity with water as an integral part and continuation of this field project.

\section{REFERENCES}

[1] R. S. Jakka, G. V Ramana, and M. Datta, "Seismic slope stability of embankments constructed with pond ash," Geotech. Geol. Eng., vol. 29, no. 5, pp. 821-835, 2011.

[2] R. Norooz, P.-I. Olsson, T. Dahlin, T. Günther, and C. Bernstone, "A geoelectrical pre-study of Älvkarleby test embankment dam: 3D forward modelling and effects of structural constraints on the 3D inversion model of zoned embankment dams," J. Appl. Geophys., vol. 191, p. 104355, 2021.

[3] H. Danso, "Suitability of Soil for Earth Construction as Building Material," Adv. Civ. Eng. Technol., vol. 2, no. 3, pp. 1-13, Oct. 2018, doi: 10.31031/ACET.2018.02.000540.

[4] A. E. Emeka, A. J. Chukwuemeka, and M. B. Okwudili, "Deformation behaviour of erodible soil stabilized with cement and quarry dust," Emerg. Sci. J., vol. 2, no. 6, pp. 383-387, 2018.

[5] R. Surendra and S. K. Bhalla, "Role of Geotechnical Properties of Soil on Civil Engineering Structures," Resour. Environ., vol. 7, no. 4, pp. 103-109, 2017, doi: $10.5923 /$ j.re.20170704.03.

[6] I. O. Igwe et al., "Formulation of Anti-Corrosive Alkyd Paints Based on Umuahia Clay Extender," Int. J. Polym. Text. Eng., vol. 7, no. 2, pp. 25-30, Jun. 2020, doi: 10.14445/23942592/IJPTE-V7I2P105.

[7] A. A. Umbugadu and O. Igwe, "Mineralogical and major oxide characterization of Panyam clays, North-Central Nigeria," Int. J. Phys. Sci., vol. 14, no. 11, pp. 108-115, 2019.

[8] K. Terzaghi, R. B. Peck, and G. Mesri, Soil Mechanics in Engineering Practice, 3rd ed. Wiley, 1996.

[9] M. Bouassida, "Improvement of soft soils," in Proceedings of International Seminar of ISSMGE "General Improvement For Accelerated Development," Accra, Ghana, 2009, pp. 147-158.

[10] Constro Facilitator, "Use of different types of clay in construction." 2020, [Online]. Available: https://www.const rofacilitator.com/use-of-different-types-of-clay-in-construct ion/\#: :text=Also a primary ingredient in,paints and ceramic building material.

[11] B. G. Look, Handbook of Geotechnical Investigation and Design Tables. London: Taylor \& Francis, 2007.

[12] C. Christson, Immanuel, and C. A. Makarim, "Analisis Tanah Dispersif terhadap Fondasi Drilled Shaft dengan Metode Casing (Dispersive Soil Analysis of Drilled Shaft Foundation with Casing Method)," J. Mitra Tek. Sipil, vol. 2, no. 2, pp. $151-160,2019$.

[13] D. Djarwadi, “Uji Dispersivitas Bahan Timbunan Bendungan Duriangkang (Duriangkang Dam Embankment 
Material Dispersivity Test)," Din. Tek. Sipil, vol. 7, no. 1, pp. $11-19,2007$.

[14] G. H. McElroy, "The use of chemical additives to control the erosive behaviour of dispersed clays," in Engineering Aspects of Soil Erosion, Dispersive Clays and Loess. Proceedings Symposium, American Society of Civil Engineers, 1987, pp. 17-29.

[15] N. L. Ryker, "Encountering Dispersive Clayson Soil Conservation Service Projects in Oklahoma," in American Society for Testing and Materials, 1976, pp. 370-389, [Online]. Available:

https://agris.fao.org/agris-search/search.do;jsessionid=E29E AFE8502571F7722E279416FA99F3?request locale $=$ fr\&re 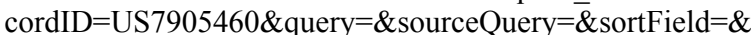 sortOrder $=$ \&agrovocString $=\&$ advQuery $=\&$ centerString $=\&$ enableField $=$.

[16] S. Sosrodarsono and K. Takeda, Bendungan Type Urugan (Earth-fill Dam). PT Pradnya Paramita, Jakarta, 1977.

[17] P. C. Knodel, "Characteristics and Problems of Dispersive Clay Soils," Colorado, 1991. [Online]. Available: https://www.usbr.gov/tsc/techreferences/rec/R-91-09.pdf.

[18] ASTM, Standard Test Methods for Identification and Classification of Dispersive Clay Soils by the Pinhole Test (ASTM D4647/D4647M-13(2020). West Conshohocken, PA: ASTM International, 2020.

[19] ASTM, Standard Test Methods for Determining Dispersive Characteristics of Clayey Soils by the Crumb Test (ASTM D6572-20). West Conshohocken, PA: ASTM International, 2021.

[20] K. L. Page, Y. P. Dang, R. C. Dalal, P. M. Kopittke, and N. $\mathrm{W}$. Menzies, "The impact, identification and management of dispersive soils in rainfed cropping systems," Eur. J. Soil Sci., vol. 72, no. 4, pp. 1655-1674, 2021.

[21] P. Rengasamy, "Irrigation water quality and soil structural stability: A perspective with some new insights," Agronomy, vol. 8 , no. 5 , p. $72,2018$.

[22] D. Norton, I. Shainberg, L. Cihacek, and J. H. Edwards, "Erosion and soil chemical properties," in Soil quality and soil erosion, CRC Press, 2018, pp. 39-56.

[23] F. L. Motta, R. Gaikwad, L. Botha, and J. B. P. Soares, "Quantifying the effect of polyacrylamide dosage, $\mathrm{Na}+$ and $\mathrm{Ca} 2+$ concentrations, and clay particle size on the flocculation of mature fine tailings with robust statistical methods," Chemosphere, vol. 208, pp. 263-272, 2018.

[24] P. Liu, S. Wang, L. Ge, M. Thewes, J. Yang, and Y. Xia, "Changes of Atterberg limits and electrochemical behaviors of clays with dispersants as conditioning agents for EPB shield tunnelling," Tunn. Undergr. Sp. Technol., vol. 73, pp. 244-251, 2018.

[25] X. Liang, P. Rengasamy, R. Smernik, and L. M. Mosley, "Does the high potassium content in recycled winery wastewater used for irrigation pose risks to soil structural stability?," Agric. Water Manag., vol. 243, p. 106422, 2021.

[26] X. Wang, P. Sale, H. Hayden, C. Tang, G. Clark, and R. Armstrong, "Plant roots and deep-banded nutrient-rich amendments influence aggregation and dispersion in a dispersive clay subsoil," Soil Biol. Biochem., vol. 141, p. 107664,2020

[27] K. E. Al-Hadedi and M. A. Al-Obidi, "Impact of cation ratio structure stability (CROSS) on the Hydraulic Conductivity Saturation and clay dispersion For some Calcareous soils in north Iraq," J. Kirkuk Univ. Agric. Sci., vol. 12, 2021. 